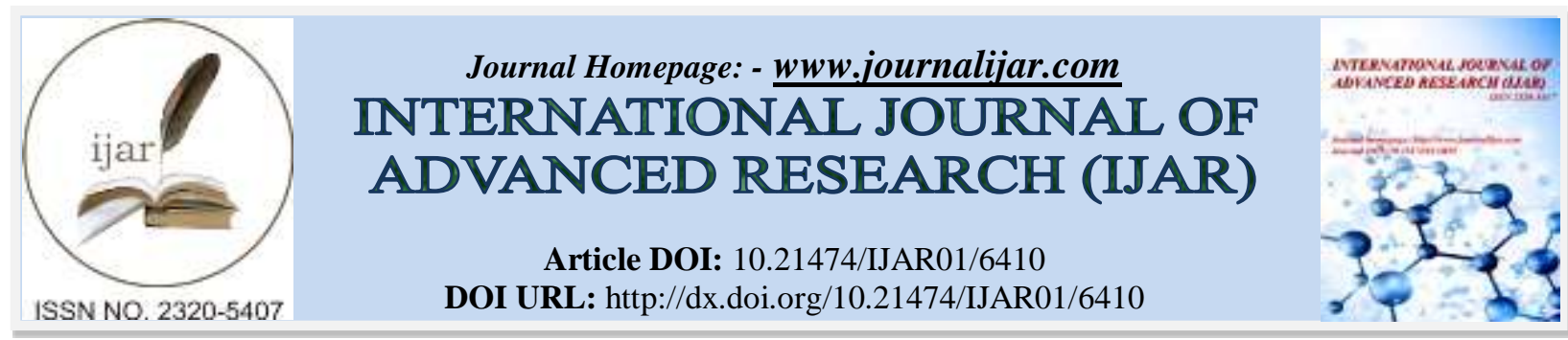

RESEARCH ARTICLE

\title{
THE VALUE OF PERFORMING EARLY TOTAL THYROIDECTOMY IN HASHIMOTO THYROIDITIS PATIENTS.
}

Ramadan Mahmoud $^{1}$, Ahmed Raafat ${ }^{1}$, Hazem Nour ${ }^{1}$, Loay M. Gertallah $^{1}$ and Mohamed Ali Alabiad $^{2}$.

1. Department of General Surgery, Zagazig University Faculty of Medicine, Zagazig, Egypt.

2. Department of Pathology, Zagazig University Faculty of Medicine, Zagazig, Egypt.

\section{Manuscript Info}

Manuscript History

Received: 01 December 2017

Final Accepted: 03 January 2018

Published: February 2018

Key words:-

early Total Thyroidectomy;

Hashimoto thyroiditis; surgical

intervention; improvement.

\section{Abstract}

The purpose of this study was to identify the value of performing total thyroidectomy in Hashimoto's thyroiditis (HT) patients with persistent preoperative symptoms despite conservative medical therapy. Additionally to identify the value of performing early total thyroidectomy in HT patients with mild to moderate preoperative symptoms without depending on medical therapy and detect the frequency of improvement of the symptoms after thyroidectomy in both conditions.

Methods: we have included 60 patients in our study who were diagnosed clinically and laboratory as having HT we divided all patients into 2 groups group 1 included 30 patients who were subjected to early total thyroidectomy and group 2 that included 30 patients and subjected to supervision and follow-up of clinical and laboratory symptoms without performing total thyroidectomy.

Patients of group 1 were subjectively evaluated for occurrence of postoperative improvement, relief of symptoms or occurrence of complications.

Results: we detected that there is marked improvement in postthyroidectomy in patients of group 1 in clinical annoying symptoms; serious tiredness, compression, voice problems $(\mathrm{p}<0.001)$, and there is marked improvement in level of antibody titers after follow-up; antiTPO antibodies, high anti-TG antibodies $(\mathrm{p}<0.001)$. In group 2 patients; we detected that there is marked deterioration in clinical annoying symptoms; serious tiredness, compression, voice problems $(p<0.001)$, and there is marked increasing in level of antibody titers after follow-up; anti-TPO antibodies, high anti-TG antibodies $(\mathrm{p}<0.001)$.

Conclusion: we have proved that total thyroidectomy for management of HT patients is an operation that can be safely performed, with low incidence of permanent complications. Therefore, HT patients will be advised to do Total Thyroidectomy early in such patients that will make antibodies disappear, improve autoimmune symptoms and decrease the incidence of postoperative complications.

Copy Right, IJAR, 2018,. All rights reserved.

Corresponding Author:- Loay M. Gertallah.

Address:- Department of General Surgery, Zagazig University Faculty of Medicine, Zagazig, Egypt. 


\section{Introduction:-}

Hashimoto's thyroiditis (HT) is an autoimmune disease that is organ specific, primarily explored in year 1912 and occurred more in females than in males, HT is the considered one of the commonest causes of hypothyroidism and diffuse or localized goiter [1-3]. Its main pathogenesis is that there are circulating multiple anti-thyroid antibodies in HT patients e.g. anti-thyroperoxidase (TPO) and anti-thyroglobulin, that cause thyroid gland destruction and lead to decrease in physiological thyroid functions $[\mathbf{4 \& 5}$ ]. HT patients are usually asymptomatic [6\&7], but in certain conditions patients might have plethora of symptoms that might be due to hypothyroidism or hyperthyroidism or alternation between hyperthyroidism and hypothyroidism, that it difficult for patients to be controlled in their hormonal levels [1\&8]. Other complaints include dysphagia, neck pain, dyspnea and hoarseness [6\&9]. Treatment for patients with HT is mostly conservative with follow-up [10\&11]. Traditionally surgical management of HT patients by performing total thyroidectomy is not recommended by most surgeons due to the severe inflammatory reaction and the variable degree of fibrosis that might surround the thyroid gland that make surgical excision difficult. Additionally when the surgeon decided to perform surgical excision of the gland, HT patients must know the possible risks that might occur, as in HT patients the thyroid gland is more liable to adhere more to its surrounding anatomical structures that might increase the risk of injury of the nearby structures like the recurrent laryngeal nerve and the parathyroid glands [5\&6]. But in certain conditions in which there is failure of medical therapy with levothyroxine (L-T4) and the patient is still suffering from HT hypothyroidism and pressure symptoms, total thyroidectomy is recommended. Generally, indications of surgery in HT patients are suspicion of malignancy, uncontrolled clinical symptoms that is related to the disease or a markedly enlarging goiter [1, 6, 9\&12]. While some studies identify and confirm the indications for surgery in HT patients [1\&7], thyroidectomy is still a controversial method of treatment [13\&14].

In our study we have hypothesized that patients with HT with or without significant compressive and annoying clinical symptoms may have a great benefits from performing early total thyroidectomy that might improve symptoms as performing early total thyroidectomy may decrease the amount of circulating antibodies like elimination of anti-TPO antibodies so improve the auto immune related symptoms e.g. tiredness, muscles and joint pain, increased need of sleep, dryness in eyes and mouth.

The purpose of this study was to identify the value of performing total thyroidectomy in HT patients with persistent preoperative symptoms despite conservative medical therapy. Additionally to identify the value of performing early total thyroidectomy in HT patients with mild to moderate preoperative symptoms without depending on medical therapy and detect the frequency of improvement of the symptoms after thyroidectomy in both conditions.

\section{Patients \& Methods:-}

I. Technical design:

A-Site of study:

This study was carried out in General Surgery\& pathology Departments, Zagazig University Hospital after having approval from the local Ethics Committee and Institutional Research Board [IRB] committee.

\section{B-Sample Size:}

We have included sixty patients in the beginning of the study that were followed up for 5 years with performing clinical and laboratory investigations every 4-6 months.

\section{C- Subject Criteria.}

Eligibility for the study

Ages: 18 Years and older

Sexes: both

\section{Criteria:-}

Inclusion Criteria:

1. Patients referred due to typical symptoms, believed to be related to Hashimoto's disease, but not relieved by thyroxin substitution. Anti-TPO> 1000

2. Hypothyroidism with a need for thyroxin supplementation 
3. Written informed consent by the patient - information particularly emphasizing and quantifying the risk of complications (e.g. recurrent laryngeal nerve palsy).

4. The patient should be informed by a medical endocrinologist as well as a surgeon.

Exclusion Criteria:

1. Patients $<18$ years of age.

2. Pregnancy.

3. Unable to comprehend information adequately to give informed consent.

4. General anaesthesiological contraindications.

5. An unexpected finding of cancer in the surgical group.

Tools:-

All patients will be subjected to:

1. Complete history taking as regard (onset, course, duration of the complaints)

2. Clinical examination.

3. Full preoperative investigations which include:

- C.B.C.

- Liver function.

- Kidney function.

- Coagulation profile.

- Blood glucose level.

- ECG.

\section{Operational design: for group 1 patients}

Type of study: comparative study. Pre-operative prophylactic Intravenous broad spectrum antibiotic will be given to all patients.

We have divided all patients into 2 groups, group 1 included 30 patients who were subjected to early total thyroidectomy and group 2 included 30 patients and subjected to only supervision and follow-up of clinical and laboratory symptoms without performing thyroidectomy. All excised thyroid are sent to pathology department to prove the diagnosis of HT

For every patient in the operated group the following will be recorded:

- The operative time.

- The need for blood and plasma transfusion.

- Oral feeding will be started after restoration of bowel movement

- The length of hospital stays (days).

- Hemorrhage.

- Wound infection.

- DVT/PE.

- Postoperative pain, wound infection, seroma, collection

- Postoperative improvement of pressure and other general symptoms and the number of patients who had improvement of preoperative symptoms after surgery was detected.

- Need for second hospital admission.

\section{Statistical Analysis:-}

We have expressed the continuous variables as mean \pm SD and checked for normality by Shapiro-Wilk test while we have expressed categorical variables as a number and a percentage that were compared using Chi-square test or Fisher's exact test. We have considered a p-value $<0.05$ as statistically significant. We have analyzed all data by using Statistical Package for Social Science for windows; 18.0 (SPSS Inc., Chicago, IL, USA).

\section{Results:-}

Basic characteristics of our patients are included in Table 1; each group included 30 patients that were mostly composed of females $26(86.7 \%$ ) in group 1 and 27 and (90)\% in group 2. mean age of our patients in group1 was $30.56 \pm 6.30$ and in group 2 was $\quad 32.26 \pm 6.17$. 


\section{Preoperative features:}

In patients in group 1 we detected that serious tiredness $(p=0.004)$ compression, voice problems $(p=0.020)$, medium and huge goiter $(0.009)$, high anti-TPO antibodies $(\mathrm{p}=108)$, high anti-TG antibodies $(\mathrm{p}=0.004)$ are more than in patients in group 2.

We

\section{Post-operative results in group 1 patients; Table 2 figure 1}

We detected that there is marked improvement in clinical annoying symptoms; serious tiredness, compression, voice problems $(\mathrm{p}<0.001)$

And there is marked improvement in level of antibody titers after follow-up; anti-TPO antibodies, high anti-TG antibodies $(\mathrm{p}<0.001)$.

\section{Pathological description of the total thyroidectomy sample; figure 2}

HT is proved by detection of excessive lymphocytic infiltrates forming lymphoid follicles and hurthle cell changes in thyroid follicles that become lined by quoiboidal cells with abundant eosinophilic cytoplasm.

\section{Post-follow up results in group 2 patients; Table 3}

We detected that there is marked deterioration in clinical annoying symptoms; serious tiredness, compression, voice problems $(\mathrm{p}<0.001)$

And there is marked increasing in level of antibody titers after follow-up; anti-TPO antibodies, high anti-TG antibodies $(\mathrm{p}<0.001)$

\section{Outcome of all patients; Table 4}

Regarding the correlation between both groups in improvement of clinical and laboratory symptoms we found a statistically highly significant results among both groups in in clinical annoying symptoms; serious tiredness, compression, voice problems ( $\mathrm{p}<0.001$ ), and level of antibody titers after follow-up; anti-TPO antibodies, high antiTG antibodies $(\mathrm{p}<0.001)$

We have proven that early total thyroidectomy gives elimination of anti-TPO antibodies $(\mathrm{p}<0.001)$, and that this elimination also eliminates the typical Hashimoto symptoms, Serious tiredness, increased need of sleep, pain in musculature and joints and dryness in eyes and mouth $(p<0.001)$. That effect is reached by performing early total thyroidectomy, as there was no other management that can remove such antibodies, and also we proved that such operation will be easily done without persistent complications like recurrent nerve damage or hypocalcaemia.

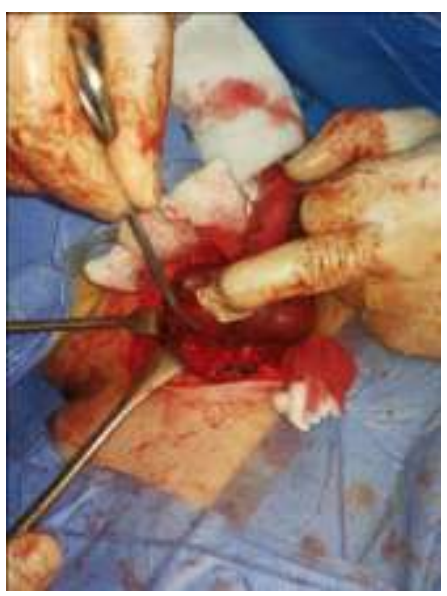

Fig 1 A 


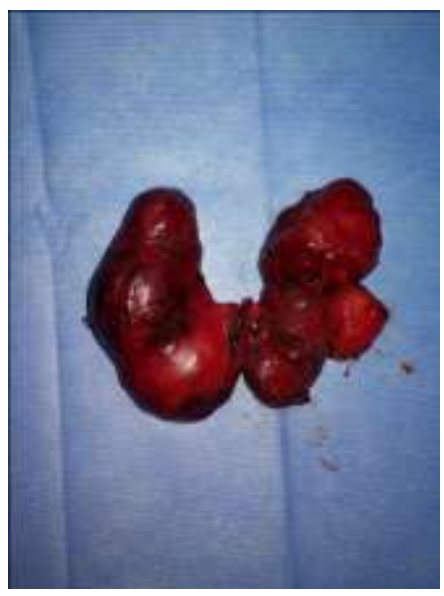

Fig 1 B

Fig (1) total thyroidectomy for HT patients; A intraoperative total thyroidectomy; B postoperative sample.

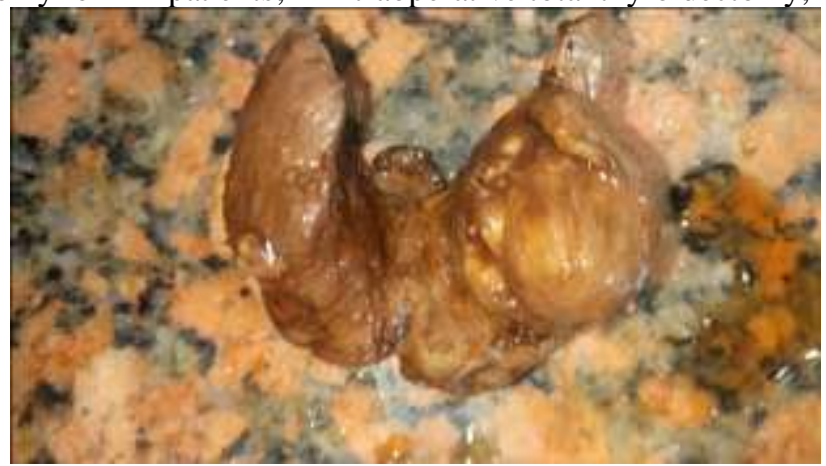

Fig 2 A

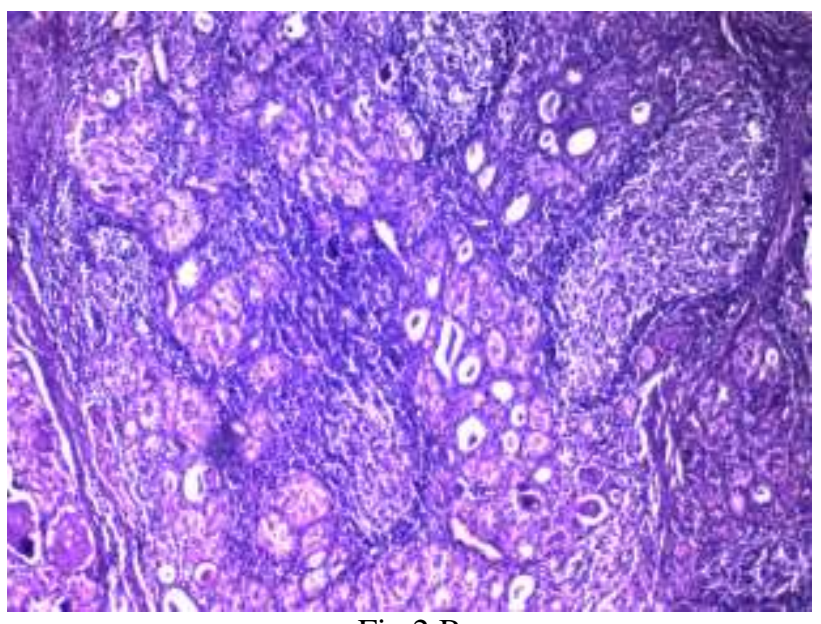

Fig 2 B 


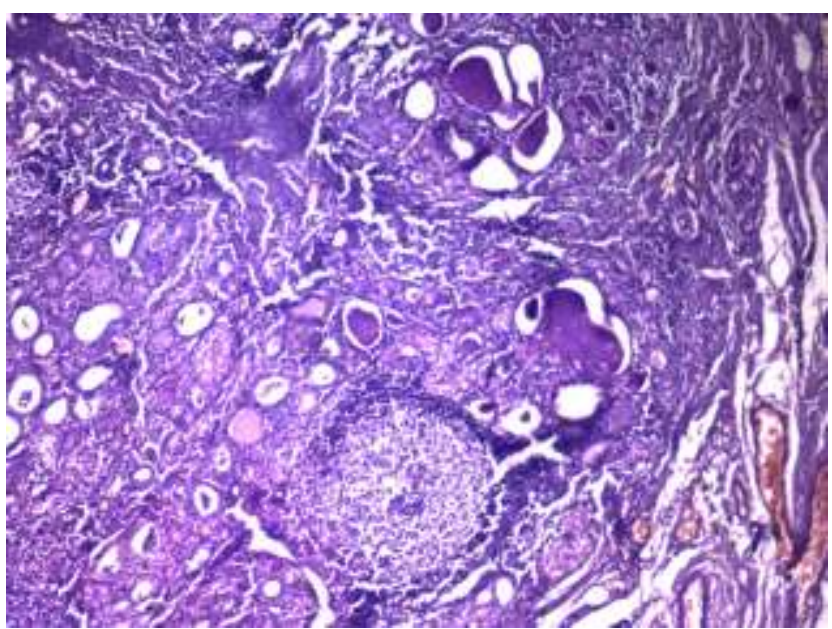

Fig $2 \mathrm{C}$

Fig (2) histopathological description of HT samples A gross description of total thyroidectomy revealed irregular shape, nodular surface and rubbery consistency; B\& C microscopic description revealed excessive lymphocytic infiltration forming lymphoid follicles with germinal center and small thyroid follicles showed hurtle cell changes.

Table 1:- basic features of our 60 patients

\begin{tabular}{|c|c|c|c|c|c|}
\hline \multirow[t]{2}{*}{ Basic characteristics } & \multicolumn{2}{|c|}{$\begin{array}{l}\text { Group1 } \\
(\mathrm{N}=30)\end{array}$} & \multicolumn{2}{|c|}{$\begin{array}{l}\text { Group } 2 \\
(\mathrm{~N}=30)\end{array}$} & \multirow[t]{2}{*}{$\mathrm{p}$-value } \\
\hline & No. & $\%$ & No. & $\%$ & \\
\hline \multicolumn{6}{|l|}{ Sex } \\
\hline Male & 4 & $13.3 \%$ & 3 & $10 \%$ & \multirow[t]{2}{*}{$1.000 \%$} \\
\hline Female & 26 & $86.7 \%$ & 27 & $90 \%$ & \\
\hline Age (years) (Mean \pm SD) & \multicolumn{2}{|c|}{$30.56 \pm 6.30$} & \multicolumn{2}{|c|}{$32.26 \pm 6.17$} & $0.232 \bullet$ \\
\hline \multicolumn{6}{|l|}{ Clinical picture } \\
\hline Serous tiredness & 18 & $60 \%$ & 7 & $23.3 \%$ & $0.004 t$ \\
\hline Pain & 9 & $30 \%$ & 4 & $13.3 \%$ & $0.117+$ \\
\hline Dryness & 14 & $46.7 \%$ & 7 & $23.3 \%$ & $0.058+$ \\
\hline Compression & 21 & $70 \%$ & 12 & $40 \%$ & $0.020 \%$ \\
\hline Voice problem & 20 & $66.7 \%$ & 11 & $36.7 \%$ & $0.020 \%$ \\
\hline Hypothyroidism symptoms & 23 & $76.7 \%$ & 15 & $50 \%$ & $0.032+$ \\
\hline \multicolumn{6}{|l|}{ Goiter } \\
\hline Small & 10 & $33.3 \%$ & 15 & $50 \%$ & $0.009+$ \\
\hline Medium & 12 & $40 \%$ & 15 & $50 \%$ & \\
\hline Huge & 8 & $26.7 \%$ & 0 & $0 \%$ & \\
\hline \multicolumn{6}{|l|}{ Laboratory findings } \\
\hline High anti-TPO antibodies & 22 & $73.3 \%$ & 16 & $53.3 \%$ & $0.108+$ \\
\hline High anti-TG antibodies & 22 & $73.3 \%$ & 11 & $36.7 \%$ & $0.004+$ \\
\hline High TSH & 23 & $76.7 \%$ & 15 & $50 \%$ & $0.032 \%$ \\
\hline Low T3 & 18 & $60 \%$ & 17 & $56.7 \%$ & $0.793 \$$ \\
\hline Low T4 & 19 & $63.3 \%$ & 17 & $56.7 \%$ & $0.598 \div$ \\
\hline
\end{tabular}

$\mathrm{N}=$ Total number of patients in each group; $\bullet$ Mann Whitney $\mathrm{U}$ test; + Chi-square test; $\mathrm{p}$-value $<0.05$ is significant.

Table 2:- Change in clinical picture and laboratory among patients in group I after performing thyroidectomy.

\begin{tabular}{|c|c|c|c|c|c|c|c|}
\hline \multirow{3}{*}{$\begin{array}{l}\text { Clinical picture pre- } \\
\text { surgical }\end{array}$} & \multicolumn{4}{|c|}{ Clinical picture post-operative } & \multirow{2}{*}{\multicolumn{2}{|c|}{ Total }} & \multirow[t]{3}{*}{ p-value } \\
\hline & \multicolumn{2}{|c|}{ Absent } & \multicolumn{2}{|c|}{ Present } & & & \\
\hline & No. & $\%$ & No. & $\%$ & No. & $\%$ & \\
\hline \multicolumn{8}{|l|}{ Serous tiredness } \\
\hline Absent & 12 & $40 \%$ & 0 & $0 \%$ & 12 & $40 \%$ & \multirow[t]{2}{*}{$<0.001+$} \\
\hline Present & 14 & $46.7 \%$ & 4 & $13.3 \%$ & 18 & $60 \%$ & \\
\hline
\end{tabular}




\begin{tabular}{|c|c|c|c|c|c|c|c|}
\hline Total & 26 & $86.7 \%$ & 4 & $13.3 \%$ & 30 & $100 \%$ & \\
\hline \multicolumn{8}{|l|}{ Pain } \\
\hline Absent & 21 & $70 \%$ & 0 & $0 \%$ & 21 & $70 \%$ & \multirow[t]{3}{*}{$0.016 \ddagger$} \\
\hline Present & 7 & $23.3 \%$ & 2 & $6.7 \%$ & 9 & $30 \%$ & \\
\hline Total & 28 & $93.3 \%$ & 2 & $6.7 \%$ & 30 & $100 \%$ & \\
\hline \multicolumn{8}{|l|}{ Dryness } \\
\hline Absent & 16 & $53.3 \%$ & 0 & $0 \%$ & 16 & $53.3 \%$ & \multirow[t]{3}{*}{$<0.001 \%$} \\
\hline Present & 12 & $40 \%$ & 2 & $6.7 \%$ & 14 & $46.7 \%$ & \\
\hline Total & 28 & $93.3 \%$ & 2 & $6.7 \%$ & 30 & $100 \%$ & \\
\hline \multicolumn{8}{|l|}{ Compression } \\
\hline Absent & 9 & $30 \%$ & 0 & $0 \%$ & 9 & $30 \%$ & \multirow[t]{3}{*}{$<0.001 \%$} \\
\hline Present & 21 & $70 \%$ & 0 & $0 \%$ & 21 & $70 \%$ & \\
\hline Total & 30 & $100 \%$ & 0 & $0 \%$ & 30 & $100 \%$ & \\
\hline \multicolumn{8}{|l|}{ Voice problem } \\
\hline Absent & 10 & $33.3 \%$ & 0 & $0 \%$ & 10 & $33.3 \%$ & \multirow[t]{3}{*}{$<0.001 \ddagger$} \\
\hline Present & 16 & $53.3 \%$ & 4 & $13.3 \%$ & 20 & $66.7 \%$ & \\
\hline Total & 26 & $86.7 \%$ & 4 & $13.3 \%$ & 30 & $100 \%$ & \\
\hline \multicolumn{8}{|l|}{$\begin{array}{l}\text { Hypothyroidism } \\
\text { symptoms }\end{array}$} \\
\hline Absent & 5 & $16.7 \%$ & 2 & $6.7 \%$ & 7 & $23.3 \%$ & \multirow[t]{3}{*}{$<0.001+$} \\
\hline Present & 20 & $66.7 \%$ & 3 & $10 \%$ & 23 & $76.7 \%$ & \\
\hline Total & 25 & $83.3 \%$ & 5 & $16.7 \%$ & 30 & $100 \%$ & \\
\hline \multirow{3}{*}{$\begin{array}{l}\text { Laboratory findings } \\
\text { pre-surgical }\end{array}$} & \multicolumn{4}{|c|}{ Laboratory findings post-surgical } & \multirow{2}{*}{\multicolumn{2}{|c|}{ Total }} & \multirow[t]{3}{*}{$\mathrm{p}$-value } \\
\hline & $\mathrm{Ab}$ & & Pre & & & & \\
\hline & $\mathrm{No}$ & $\%$ & No. & $\%$ & No. & $\%$ & \\
\hline \multicolumn{8}{|l|}{$\begin{array}{ll}\text { High } & \text { anti-TPO } \\
\text { antibodies }\end{array}$} \\
\hline Absent & 8 & $26.7 \%$ & 0 & $0 \%$ & 8 & $26.7 \%$ & \multirow[t]{3}{*}{$<0.001+$} \\
\hline Present & 18 & $60 \%$ & 4 & $13.3 \%$ & 22 & $73.3 \%$ & \\
\hline Total & 26 & $86.7 \%$ & 4 & $13.3 \%$ & 30 & $100 \%$ & \\
\hline \multicolumn{8}{|l|}{ High anti-TG antibodies } \\
\hline Absent & 8 & $26.7 \%$ & 0 & $0 \%$ & 8 & $26.7 \%$ & \multirow[t]{3}{*}{$<0.001 \ddagger$} \\
\hline Present & 17 & $56.7 \%$ & 5 & $16.7 \%$ & 22 & $73.3 \%$ & \\
\hline Total & 25 & $83.3 \%$ & 5 & $16.7 \%$ & 30 & $100 \%$ & \\
\hline
\end{tabular}

$\ddagger$ McNemar's test; $p$-value $<0.05$ is significant.

Table 3:- Change in clinical picture and laboratory findings among patients in group II.

\begin{tabular}{|c|c|c|c|c|c|c|c|}
\hline \multirow{3}{*}{$\begin{array}{l}\text { Clinical picture pre- } \\
\text { surgical }\end{array}$} & \multicolumn{4}{|c|}{ Clinical picture post-surgical } & \multirow{2}{*}{\multicolumn{2}{|c|}{ Total }} & \multirow[t]{3}{*}{ p-value } \\
\hline & \multicolumn{2}{|c|}{ Absent } & \multicolumn{2}{|c|}{ Present } & & & \\
\hline & No. & $\%$ & No & $\%$ & No. & $\%$ & \\
\hline \multicolumn{8}{|l|}{ Serous tiredness } \\
\hline Absent & 8 & $26.7 \%$ & 15 & $50 \%$ & 23 & $76.7 \%$ & \multirow[t]{3}{*}{$<0.001 \%$} \\
\hline Present & 0 & $0 \%$ & 7 & $23.3 \%$ & 7 & $23.3 \%$ & \\
\hline Total & 8 & $26.7 \%$ & 22 & $73.3 \%$ & 30 & $100 \%$ & \\
\hline \multicolumn{8}{|l|}{ Pain } \\
\hline Absent & 11 & $36.7 \%$ & 15 & $50 \%$ & 26 & $86.7 \%$ & \multirow[t]{3}{*}{$<0.001 \%$} \\
\hline Present & 0 & $0 \%$ & 14 & $13.3 \%$ & 4 & $13.3 \%$ & \\
\hline Total & 11 & $36.7 \%$ & 19 & $63.3 \%$ & 30 & $100 \%$ & \\
\hline \multicolumn{8}{|l|}{ Dryness } \\
\hline Absent & 9 & $30 \%$ & 14 & $46.7 \%$ & 23 & $76.7 \%$ & \multirow[t]{3}{*}{$<0.001 \%$} \\
\hline Present & 0 & $0 \%$ & 7 & $23.3 \%$ & 7 & $23.3 \%$ & \\
\hline Total & 9 & $30 \%$ & 21 & $70 \%$ & 30 & $100 \%$ & \\
\hline \multicolumn{8}{|l|}{ Compression } \\
\hline Absent & 5 & $16.7 \%$ & 13 & $43.3 \%$ & 18 & $60 \%$ & $<0.001 \%$ \\
\hline
\end{tabular}




\begin{tabular}{|c|c|c|c|c|c|c|c|}
\hline Present & 0 & $0 \%$ & 12 & $40 \%$ & 12 & $40 \%$ & \\
\hline Total & 5 & $16.7 \%$ & 25 & $83.3 \%$ & 30 & $100 \%$ & \\
\hline \multicolumn{8}{|l|}{ Voice problem } \\
\hline Absent & 5 & $16.7 \%$ & 14 & $46.7 \%$ & 19 & $63.3 \%$ & \multirow[t]{3}{*}{$<0.001 \%$} \\
\hline Present & 0 & $0 \%$ & 11 & $36.7 \%$ & 11 & $36.7 \%$ & \\
\hline Total & 5 & $16.7 \%$ & 25 & $83.3 \%$ & 30 & $100 \%$ & \\
\hline \multicolumn{8}{|l|}{$\begin{array}{l}\text { Hypothyroidism } \\
\text { symptoms }\end{array}$} \\
\hline Absent & 11 & $36.7 \%$ & 4 & $13.3 \%$ & 15 & $50 \%$ & \multirow[t]{3}{*}{$0.049 \ddagger$} \\
\hline Present & 13 & $43.3 \%$ & 2 & $6.7 \%$ & 15 & $50 \%$ & \\
\hline Total & 24 & $80 \%$ & 6 & $20 \%$ & 30 & $100 \%$ & \\
\hline \multirow{3}{*}{$\begin{array}{l}\text { Laboratory findings } \\
\text { pre-surgical }\end{array}$} & \multicolumn{4}{|c|}{ Laboratory findings post-surgical } & \multirow{2}{*}{\multicolumn{2}{|c|}{ Total }} & \multirow[t]{3}{*}{ p-value } \\
\hline & \multicolumn{2}{|c|}{ Absent } & \multicolumn{2}{|c|}{ Present } & & & \\
\hline & No. & $\%$ & No. & $\%$ & No. & $\%$ & \\
\hline $\begin{array}{ll}\begin{array}{l}\text { High } \\
\text { antibodies }\end{array} & \text { anti-TPO } \\
\end{array}$ & & & & & & & \\
\hline Absent & 6 & $20 \%$ & 8 & $26.7 \%$ & 14 & $46.7 \%$ & \multirow[t]{3}{*}{$0.008 \$$} \\
\hline Present & 0 & $0 \%$ & 16 & $53.3 \%$ & 16 & $53.3 \%$ & \\
\hline Total & 6 & $20 \%$ & 24 & $80 \%$ & 30 & $100 \%$ & \\
\hline \multicolumn{8}{|l|}{ High anti-TG antibodies } \\
\hline Absent & 8 & $26.7 \%$ & 11 & $36.7 \%$ & 19 & $63.3 \%$ & \multirow[t]{3}{*}{$0.001 \%$} \\
\hline Present & 0 & $0 \%$ & 11 & $36.7 \%$ & 11 & $36.7 \%$ & \\
\hline Total & 8 & $26.7 \%$ & 22 & $73.3 \%$ & 30 & $100 \%$ & \\
\hline
\end{tabular}

$\$$ McNemar's test; $p$-value $<0.05$ is significant.

Table (4): correlations between both groups regarding outcome of treatment

\begin{tabular}{|c|c|c|c|c|c|}
\hline \multirow[t]{2}{*}{ Outcome of treatment } & \multicolumn{2}{|c|}{$\begin{array}{l}\text { Group I } \\
(\mathrm{N}=30)\end{array}$} & \multicolumn{2}{|c|}{$\begin{array}{l}\text { Group II } \\
(\mathrm{N}=30)\end{array}$} & \multirow[t]{2}{*}{ p-value } \\
\hline & No. & $\%$ & No. & $\%$ & \\
\hline \multicolumn{6}{|l|}{ Clinical picture } \\
\hline Serous tiredness & 4 & $13.3 \%$ & 22 & $73.3 \%$ & $<0.001 \%$ \\
\hline Pain & 2 & $6.7 \%$ & 19 & $63.3 \%$ & $<0.001 \%$ \\
\hline Dryness & 2 & $6.7 \%$ & 21 & $70 \%$ & $<0.001 \%$ \\
\hline Compression & 0 & $0 \%$ & 25 & $83.3 \%$ & $<0.001 \%$ \\
\hline Voice problem & 4 & $13.3 \%$ & 25 & $83.3 \%$ & $<0.001 \%$ \\
\hline Hypothyroidism symptoms & 5 & $16.7 \%$ & 6 & $20 \%$ & $0.739 \$$ \\
\hline \multicolumn{6}{|l|}{ Laboratory findings } \\
\hline High anti-TPO antibodies & 4 & $13.3 \%$ & 24 & $80 \%$ & $<0.001 \%$ \\
\hline High anti-TG antibodies & 5 & $16.7 \%$ & 22 & $73.3 \%$ & $<0.001 \%$ \\
\hline High TSH & 5 & $16.7 \%$ & 6 & $20 \%$ & $0.739 \$$ \\
\hline Low T3 & 5 & $16.7 \%$ & 6 & $20 \%$ & $0.739 \$$ \\
\hline Low T4 & 5 & $16.7 \%$ & 6 & $20 \%$ & $0.739 \$$ \\
\hline \multicolumn{6}{|l|}{ Complications } \\
\hline Transient complications & 8 & $26.7 \%$ & 11 & $36.7 \%$ & $0.405 \$$ \\
\hline Permanent complications & 4 & $13.3 \%$ & 18 & $60 \%$ & $<0.001 \%$ \\
\hline
\end{tabular}

$\$$ Chi-square test; $\mathrm{p}$-value $<0.05$ is significant.

\section{Discussion:-}

[PIETRO ACCETTA et al., [15] stated that HT is progressive clinicopathological condition that is considered a main reason of primary hypothyroidism. HT could be diagnosed clinically by presence of clinical evidence of goiter as compression manifestation and hypothyroidism like easy fatigability, muscle and bone pain. Additionally, blood tests, ultrasound that showed an enlarged gland, with variable texture, variable sized nodules help in the diagnosis of HT. Management of HT patients depends on the severity of symptoms that the patients suffer from. 
As a general rule, for HT patients total thyroidectomy is indicated in cases of suspicion of malignancy, persistent severe symptoms as pain, discomfort and pressure symptoms due to markedly enlarging goiter which is not responding to conservative medical therapy $[1,10,6,12,16]$. Also, in patients that fluctuate between a hyperthyroid and a hypothyroid state and could not permanently control their hormone levels, which make them, seek for other options that could allow adequate management and relieve their symptoms. Performing total thyroidectomy is recommended for those patients with marked pressure symptoms, such as dysphagia and dyspnea that resulted from a markedly enlarging goiter that is pressing on the esophagus and the trachea $[\mathbf{9 , 1 3 ] .}$

Catherine McManus et al., [14], have proved that HT patients were significantly younger in age and more likely to be female, which is consistent with other our results and with previous reports $[\mathbf{2 , 6 , 1 7 ]}$.

We hypothesized in our current research that HT patients that presented with/or without significant compressive and other autoimmune related symptoms will have benefit from performing early total thyroidectomy for better management. Our results have proved that total thyroidectomy will eleminate anti-TPO antibodies $(\mathrm{p}=0.011)$, and that this elimination also eliminates the typical Hashimoto autoimmune symptoms, e.g. serious tiredness, increased requirement for sleeping, muscle and joint pain and dryness in eyes and mouth $(\mathrm{p}=0.019)$. I was found formerly that there is no other existing treatment which can eliminate these antibodies. Moreover we have also proven that early total thyroidectomy can be performed without serious late persistent complications e.g. recurrent nerve damage and hypocalcaemia $(\mathrm{p}=0.000)$. There was a statistically significant difference between both of our groups groups regarding improvement of autoimmune and compressive symptoms. The benefits and indications of surgery in HT patients that we have proved in our study were consistent with other previous results found by Thomas et al. [1]\& Shimizu, et al. [7], that have clarified indications for total thyroidectomy for HT patients ; (1) compressing neck mass that is unresponsive to suppressive medical therapy; 2) progressively enlarging goiter that not responsive to conservative suppressive therapy; 3 ) clinical suspicious of malignancy. We add to such indications that as HT is a progressive disease and finally in all cases will need surgical interventions so it is better for total thyroidectomy to be performed early to improve compressive and other autoimmune symptoms by elimination of auto immune antibodies. Previous authors have established definitive criteria for thyroidectomy in patients with HT, but unlike our research they did not evaluate the patients after thyroidectomy to detect improvement of preoperative symptoms postoperatively or occurrence of postoperative complications from the surgery [Thomas et al., 1981, Shih et al., 2008, Tajiri et al., 2006]. But we have stated that in addition to these indications we can perform early total thyroidectomy in HT even in absence of pressure symptoms as that will decrease the level of anti-bodies thus will improve the symptoms and decrease the incidence of post-operative complications which we have proved during follow up of our patients for 24 months with performing radiological and laboratory investigations every 2-6 months.

Although we have confirmed that HT is a surgical problem that must need asurgical excision in nearly all cases like results of previous studies [1, 6, 9], but Catherine McManus et al., [14], have found different results that HT patients undergoing total thyroidectomy will be more significantly liable to higher rates of postoperative transient complications and permanent complications such different results may be because they have performed total thyroidectomy late which increase the liability for adhesion and injury to neighboring structures. That add more to our results in that HT is a risk factor that is associated with increased postoperative complications and adhesions if there is a delay in its performance. We have given a careful consideration preoperatively in HT patients to informed consent regarding the increased risks of surgery.

Most of our patients have reported no annoying symptoms after total thyroidectomy. Even the few patients who have suffered from transient postoperative complication experienced relief of preoperative compressive and autoimmune symptoms postoperatively, surgery have served as a long term benefit to them once the complication resolved. The remaining 4 patients we have few patients who did not have relief of preoperative autoimmune symptoms and have suffered from transient postoperative complication like mild hypoparathyroidism and vocal cord injury, that have resolved within 6 months and they have relief of the compression symptoms.

In conclusion, we have proved that total thyroidectomy for management of HT patients is an operation that can be safely performed, with low incidence of permanent complications, which allows one to broaden its indications to HT patients, that help to avoid future recurrence of the symptoms and reoperations In our study, the majority of patients with HT that were suffering from significant symptoms have reported marked improvement and relief of preoperative symptoms after performing total thyroidectomy. So, HT patients always will need surgery for active 
real management that will give better relief of symptoms than conservative medical therapy palliation. Therefore, HT patients will be advices to do surgery if they are suffering from persistent symptoms after conservative therapy, moreover, it will be better to perform Total Thyroidectomy early in such patients that will make antibodies disappear, improve autoimmune symptoms and decrease the incidence of postoperative complications.

\section{References:-}

1. Thomas CG, Rutledge RG. Surgical intervention in chronic (Hashimoto's) Thyroiditis. Ann Surg. 1981; 193:769-776. [PubMed: 6894684]

2. Repplinger D, Bargren A, Zhang Y, Adler J, Haymart M, Chen H. Is Hashimoto's thyroiditis a risk factor for papillary thyroid cancer? J Surg Res. 2008; 150:49-52. [PubMed: 17996901]

3. Gasbarri A, Sciacchitano S, Marasco A, Papotti M, et al. Detection and molecular characterization of thyroid cancer precursor lesions in a specific subset of Hashimoto's thyroiditis. British J of Cancer. 2004; 91:10961104.

4. Beobachtungen K. Indication of operation in various forms of Hashimoto's thyroiditis. Clinical observations. Munch Med Wochenschr. 1975; 117(13):543-6.

5. Stoll SJ, Pitt SC, Liu J, Schaefer S, Sippel RS, Chen H. Thyroid hormone replacement after thyroid lobectomy. Surgery. 2009; 146(4):558-60.

6. Shih ML, Lee JA, Hsieh CB, et al. Thyroidectomy for Hashimoto's thyroiditis: complications and associated cancers. Thyroid. 2008; 18(7):729-34. [PubMed: 18631001]

7. Shimizu K, Nakajima Y, Kitagawa W, Akasu H, et al. Surgical therapy in Hashimoto's thyroiditis. J Nippon Med Sch. 2003; 70(1):34-9. [PubMed: 12646974].

8. Zaletel K. Determinants of thyroid autoantibody production in Hashimoto's thyroiditis. Exp Rev of Clin Immunol. 2007; 3(2):217-23.

9. Tajiri J. Radioactive iodine therapy for goitrous Hashimoto's thyroiditis. J Clin Endocrinol Metab. 2006; 91(11):4497-500. [PubMed: 16895949].

10. Cipolla C, Sandonato L, Graceffa G. Hashimoto thyroiditis coexistent with papillary thyroid carcinoma. Am Surg. 2005; 71:874-8. [PubMed: 16468540]

11. Gyory F, Lukacs G, Juhasz F, et al. surgically treated Hashimoto's thyroiditis. Acta Chir Hung. 1999; 38(34):243-7. [PubMed: 10935132]

12. Haymart MR, Repplinger DJ, Leverson GE, Elson DF, Sippel RS, Jaume JC, Chen H. Higher Serum TSH Level in Thyroid Nodule Patients is Associated with Greater Risks of Differentiated Thyroid Cancer and Advanced Tumor Stage. Journal of Clinical Endocrinology and Metabolism. 2008; 93:809-14. [PubMed: 18160464].

13. Catherine McManus, B.S., Jie Luo, B.S., Rebecca Sippel, M.D., F.A.C.S., and Herbert Chen, M.D., F.A.C.S Should Patients with Symptomatic Hashimoto's Thyroiditis Pursue Surgery? J Surg Res. 2011 September; 170(1): 52-55. doi:10.1016/j.jss.2011.01.037.

14. Catherine McManus, B.S., Jie Luo, B.S., Rebecca Sippel, M.D., F.A.C.S., and Herbert Chen, M.D., F.A.C.S. Is Thyroidectomy in Patients with Hashimoto's Thyroiditis More Risky? J Surg Res. 2012 December; 178(2): 529-532. doi:10.1016/j.jss.2012.09.017.

15. PIETRO ACCETTA, TCBC-RJ 1; ITALO ACCETTA TCBC-RJ 1; ANTONIO CARLOS ACCETTA TCBCRJ 1; MARCELO SÁ DE ARAÚJO TCBC-RJ 1; RENATO ACCETTA 1; KEILA BORBA CAMPOS 2 Total thyroidectomy for benign thyroid diseases Rev. Col. Bras. Cir. 2011; 38(4): 223-226

16. Nenkov R, Radev R, Khristozoc K, Kuzmanov Ia, et al. Hashimoto's thyroiditis: indications for surgical treatment. Khirurgiia(Sofiia). 2005; (3):28-32.

17. Kurukahvecioglu O, Taneri F, Yuksel O, et al. Total thyroidectomy for the treatment of Hashimoto's thyroiditis coexisting with papillary thyroid carcinoma. Adv Ther. 2007; (3):510- 516. [PubMed: 17660159] 